\title{
Status of the Modern General Theory of the State and Law in the System of the Legal Sciences
}

\author{
Vladimir Valentinovich Kozhevnikov \\ Departmen of theory and history of state and law, Dostoevsky Omsk State University, Omsk, Russia \\ kta6973@rambler.ru
}

\begin{abstract}
This scientific article deals with the problem of the hierarchy of the modern legal sciences. The main purpose of the work is to justify the principle that modern general theory of the state retains the status of the fundamental, methodological legal science. There are following tasks of the achieving of the purpose in the article: 1) to analyse the positions of the legal scientists who doubt on the high status of the general theory of the state and the law; 2) to characterize Marxist-Leninist general theory of state and law, which had class, party character; 3) to justify the position that certain provisions of Marxism-Leninism have not lost relevance yet; 4) to display the similarity of MarxistLeninist general theory of the state and law and modern theory of state and law in terms of methodological foundations. Result. Not agreeing that the theory of the state and law has the function of the serving of the official ideology currently, there is a suggestion in the article that the general theory of the state and law at all stages of the development of the society, not excluding the modern science, is the fundamental, methodological science in the system of other legal sciences, despite the attacks at both theoretical and practical levels.
\end{abstract}

Keywords

theory of thestateandlaw, methoddogical science, downgrade of thestatus of science, ideology of Marxism-Leninism legal education

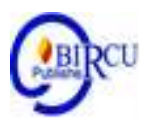

\section{Introduction}

The reason for the writing of the scientific article was the attack of some theorists who doubt on the significance of the modern general theory of the state and law as a fundamental, methodological science.

\section{Research Methods}

The following methods were used in the preparation of the scientific article:

\subsection{General Philosophical}

General philosophical (dialectico-materialist), which is used in all social sciences

a. Popular science (analysis and synthesis, logical and historical, comparisons, abstractions and others), which are used not only by state and law theory, but also by other social sciences;

b. Special methods (philological, cybernetic, psychological and other) wich are developed by special sciences and widely used for knowledge of public legal phenomena;

c. Private-scientific (formal-legal, interpretations of law and others), which are developed by the theory of state and law. 
2.2 Downplaying the Status of the Modern General State Theory and Law at the Theoretical Level

We believe that the title of the scientific article in the form of the question is quite legitimate and justified against the background of the theoretical provisions that argue otherwise. Thus, the team of sufficiently authoritative theoretical scientists are inconsistent because earlier they justified the completely different position, considering the place of the theory of the state and law in the system of the not social sciences, as the authors believe, but legal, they write that "the history of the state and the law is basic in relation to the theory of the state and the law" (Radko, 2012).

The negative assessment of the theory of the state and law, the decline of its status for the jurisprudence, takes place also in the work of another team of the scientists. They wrote the theory of the state and law in modern conditions performs has the function of servicing of the official ideology, and the concepts of "Human rights", "constitutional state" have the same ideological stamps as before "nationwide state" or "socialist democracy" and note that "the traditional methodological and futurological function for the theory of state and law is performed by the branch sciences, and therefore the theory loses the importance of the fundamental, generalizing legal science" (Polyakov, 2000).

One of the authors of this unfounded view is Roman Anatolyevich Romashov. In one of his works, the scientist stressed that "the theory of state and law is a fundamental legal science, and then, again - stressing that this science has an important place in the system of domestic legal education (Romashov, 2010), goes back on his word, saying that on this issue there are different views, often contradictory, and sometimes mutually exclusive, believes the following: "This circumstance, on the one hand, testifies to the pluralistic nature of the modern Russian jurisprudence, and on the other hand, is an indicator of the uncertainty of the targets that are guided in their activities by representatives of domestic legal science and education" (Romashov, 2010).

\subsection{Deideologization of the Modern Theory of the State and Law}

Scientists persistently do not want to see the process of so-called deideologization of the modern theory of the state and law, which is analyzed by Eugene Ivanovich Temnov. In particular, the author believes that "the problem of the methodological renewal that faced the political and legal science requires from the educational process a purely creative and realistic approach, a critical assessment of the achieved, attentive and responsible perception of the new. Rejection of the dogmatism, the revision of the available theoretical baggage presuppose the constructively of the methodological prerequisites themselves, the interaction in some cases with theoretical constructions of the opponents "(Temnov, 1997).

It is difficult to agree with scholars downplaying the status of the general theory of the state and law, which they believe performs a "function of the serving official ideology." From the author's point of view, "in our "deideologized" consciousness, the tendency towards the social primitive, mass aberrations has benn increasing (i.e., misconceptions-Vladimir Valentinovich Kozhevnikov), loss of already weak immunities from charismatic, nationalist populism "(Sinyukova). In his time Daniel Alexandrovitch Granin wrote: "Recently the intelligentsia had the idea of the opposing the regime, the monstrous Soviet ideology. There was no ideology, and there was no one to resist. "(Granin, 2000)

The constitutional state is only an ideal that expresses the official legitimate position of our State. As for the issue of the Russian legal ideal, Rustam Suleimanovich Bayniazov emphasizes, historically, the constitutional state is not become a national ideal for Russian citizens. On the contrary, there is disbelief, skepticism, apathy in people's minds about this. The spiritual situation in Russia is such that the communist myth has long been dispelled, old 
"ideals" have been discarded, and there are virtually no new ones, and if there are ones they are not always adequate to the popular spirit (Bayniyazov, 2001).

It is important to note that some legal scholar have given attentions the ideological aspects of legal science. Thus, Anisim Ivanovich Ekimov, highlighting two points of view in the context of this issue, emphasizes that according to the first position, it is necessary to strive for deideologization of scientific knowledge; there is a legal truth independent of political interests, reflecting universal human values (recognized in a particular historical era or unchanged at all times). According to the second, only ideologized properly knowledge can carry the truth; All legal is fundamentally political, and the law itself is a political measure. The concept of "ideology" is understood and appreciated differently: if the essence of ideology is that it is a set of paradigm, or ideology, that serves the interests of a narrow circle of chosen, then indeed legal science should, as far as possible, distance itself from it; If ideology is a set of different ideas reflecting the essence of what is happening more or less accurately, then a different situation arises (Ekimov, 1996).

\section{Discussion}

\subsection{Class, Party Character of Marxist-Leninist General Theory of State and Law}

Indeed, after 1917, jurisprudence was put at the service of class interests, which, however, in practice were interpreted exclusively from the position of administrative command top. Entire sections of the state theory and law (on the concept of the state and law, on the functions of the state, etc.) have been fundamentally revised. Instead of the ideological pluralism characteristic of the pre-revolutionary era, for many decades a monopoly on the truth for Marxism- Leninism is established. Accordingly, the theory of state and law began to be called no other than Marxist-Leninist.

In that period, only the views of pre-Marxian theoretical thought or concept based on the ideas of Karl Marx and Vladimir Lenin were considered in positive terms. Non-Marxist and anti-Marxist thought was either ignored or served as a target for attacks, and there was nothing positive in it. Modern Western state legal systems were presented as hostile to the interests of the masses and unable to ensure the rights and interests of the general population. The legal science itself was proclaimed as party, serving the interests of the proletariat. At the same time, it was argued that the interests of the proletariat are the real interests of society. Therefore, everything that contradicts them is objectively contrary to the interests of society.

A very common thesis in the legal literature was that the state and law were subject to class interests, and as the class division of society lost the meaning, the state and law would die. In the post-October period, Soviet philosophical-legal thought in views on the state was unchanged: it was mainly oriented towards more in depth disclosure of the class character of the state in any manifestations, including socialist ones. There was a statement in the philosophical dictionary of that time that "the state is the political organization of the economically dominant class with the aim of the protecting of the existing economic order and suppressing the resistance of other classes" (Gospolizdat, 1941).

It was recommended to find the class meaning of specific legal norms, concrete state decisions. As a result of the "party" approach, the legal science has lost an objective approach to the analysis of State legal phenomena. First of all, it was expressed both in the theory and in the practice in disregard of the interests of the individual and his rights. The independent status and value of the individual, certain person as the subject of economy, the right and policy were denied. The radical rejection of the individual in favor of the universal (social, collective) has led to the comprehensive transformation of a man into a living instrument and an auxiliary means of the universal whole, into a simple performer of the corresponding 
functions of proletarian organized collectivity and socialist community, in short, into an impersonal, ordinary, disempowered "screw" of a single huge machine of collective suppression, violence, power-centralized production, distribution and consumption. In this regard, it seems appropriate to give the reflection of Daniel Alexandrovitch Granin as the criticism of Soviet science "It is impossible to artificially stop the course of science. But humanization is necessary. It became clear that rational and logical development of science showed its insufficiency "(Granin, 2000).

Marxist dogma was established in the Russian legal science in steps. The dominance of the dogmatic concept, its monopoly position, that was established in 1930 and partly preserved up to the present, has become a true tragedy of our law. The Soviet legal science has become an ideological superstructure over the basis of the command and administrative system, for which the legislation served as an instrument to combat the "internal and external" enemy, to secure its dominant position, to achieve its own goals. The main duties of the legal science were reduced to analysis, commenting and apologetics of the law. The domestic law school gradually is transformed into a school of beginnings and deaf dogmatism. Here, it seems that the assertion of Daniel Alexandrovitch Granin, who wrote that "junk science" was supposed to show everyone that ideology is above the truth, that the interests of politics are above the interests of science," is very appropriate (Granin, 2000). Such a characteristic can be quite used in an objective assessment of Marxist-Leninist general theory of the state and law.

In this regard, Eugene Ivanovich Temnov notes that "ideologized positions of the researcher did not allow to fully trace the historical trajectory, involvement in spiritual orientations of the past. Monopolism, one-dimensional and unidirectional analysis did not take into account the contradictory, dual nature of the observed phenomena - law and State. The content of the class approach was gradually made up of ideological intolerance and closure. The degree of democratization of theories was determined by the role that the thinker assigned to the working segments of the civilian population, the potential of superiority of trends and goals of the oppressed class over the manifestation of universal trends and aims" (Temnov, 1997). The scheme of the Marxist-Leninist approach was based on economic determinism: the state and law arise as a result of the emergence of the private property, and its consequence is the division of society into antagonistic classes, reconciliation of enmity between which is possible through the state and law. Marxism was entirely based on a formative approach. The teachings of the legal and social State fell out of sight.

\subsection{Criticism of Marxism-Leninism}

On the contrary, there is now a militant rejection and ruthless criticism of this approach. At the same time, it should be taken into account that any theory, using its methods of knowledge, carries pieces of knowledge in the general savings box, allows understanding deeper and more fully certain facets of the studied phenomena. Apparently, today the most acceptable for the legal science is the so-called constructive - critical approach to evaluation and analysis of past and present state-legal doctrines. This is also fully true of MarxistLeninist doctrine, which has been severely criticized and even vilified, including its former "hot" supporters. The protracted systemic crisis in many socialist countries, the vital need to overcome it, led to a sharply negative attitude towards Marxism - Leninism as teaching and socialism as a social and political structure. Noting that "quite recently any study of the legal validity" was determined by methodological principles of Marxist philosophy," which in the theory of knowledge at the present time by some researchers have been put on the background, Andrei Ivanovich Bryazgalov believes that... "at present such guidelines are also lost to some extent in the legal science"(Bryzgalov, 2004). 


\subsection{The Provisions of Marxism-Leninism, Which are of Lasting Importance}

However, the science cannot fall into the extreme. There is no dispute, there is a lot of utopian and outdated in Marxism, but there are some provisions and conclusions that are of constant importance (for example, ideas about collectivism, social justice, etc.).

By the way, the domestic theoretical scientists payed attention to the aspect of this problem. Thus, Eugeniy Ivanovich Temnov, believing that for the study of complex periods of history or confrontation of ideological views it is possible to take into account class interest, emphasizes that... "such an approach should not turn into an exceptional and selfgoverning approach (as was the case in the Marxist-Leninist general theory of the state and law- Kozhevnikov Vladimir Valentinovich) in the methodological arsenal of the study." Reflecting on the methodology of knowledge of state-legal reality, the author argues that "to see after partisanship and classicality more than one of the method of knowing, a specific methodological approach and to erect it into a universal principle it means to ideologize the means of the scientific analysis, and, ultimately, its results" (Temnov, 1992).

Orest Vladimirovich Martyshin, reflecting on the concept of the state, notes that until the 1990s the Marxist-Leninist concept of the class nature of the state dominated without separation in our country, but then it began to be displaced by the perceptions of the state as a good of civilization, serving not class, but general interests. The author reveals the following trend in the domestic legal science: one extreme of the Marxist interpretation of the state in the Soviet version is replaced by another of the unilateral statement that the state serves the common good and only it, and the differences between the essence and the proper are blurred (Martysciin, 2002). For example, Vladimir Alexandrovitch Tshetvernin believes that "the state power serves society and therefore expresses general interest: ensuring the integrity and stability of the social system. But the state power in addition to the general interest expresses the interests of private individuals: ensuring freedom, security and property" (Chetvernin, 2003).

\subsection{The Method of Dialectical and Historical Materialism as a General Philosophical Method of the Modern General Theory of the State and Law}

It is not difficult to notice, and this is important in the context of the present work, that despite the criticism of Marxism-Leninism, the vast majority of modern theoretical scientists prefer the method of dialectical dialectics as a general philosophical (universal, worldview) method. It seems that this method has not lost its relevance in the legal research. A number of other scientists express their solidarity with this confirmation. For example, the team of authors of the textbook on the philosophy of law believes that "at the heart of the synthesizing qualities of the philosophy of law is the confirmation that the core of the philosophy as a methodological science is the unity of dialectics, logic and the theory of knowledge. This means generically that the same system of laws and categories in dialectic acts as principles of knowledge of the objective world, in the theory of cognition as a means of solving specific cognitive problems and in logic as a form of scientific thinking" (Baranov, 2004).

Viktor Mikhailovich Korelsky states in the categorical form that "our domestic science has an orientation towards the materialistic approach, according to which the deep essential sides of the state and rights are ultimately determined by the economy, forms of ownership. The materialist approach makes it possible to trace the connection of the State and law to the real processes and to explore their possibilities for strengthening the material foundations and increasing the economic potential of society." According to the scientist, "the philosophical basis of the theory of the state and law is the dialectical method, i.e. the teaching about the most common natural connections of the development of being and consciousness" (Korelsky, 2000). Recognizing that the method of dialectical and historical materialism has made a huge contribution to the knowledge of the political and legal reality, Vyacheslav 
Nikolaevich Zhukov writes in his work that "currently it is characteristic to deal with the state and law in the development, historically, in the unity of the political, spiritual and economic life of the society, relying on public practice as a criterion of truth (Kozhevnikov, 2014) of the methodology of theoretical and legal science. "(Zhukov, 2019). In the variety of in modern science used approaches there is a dialectical-materialist methodology and from the point of view of Valeriy Pavlovich Kohanovsky, it plays an increasing role (Kokhanovsky, 2005).

Domestic scientists, in our view, state quite rightly that there are no convincing arguments against the use of materialist dialectics as one of the options of theoretical world view and elements of the methodology of scientific research to date. As the authors state, "in the modern philosophical market it is quite competitive" (Baranov, 2007). As a supporter of Marxist theory of law Vladimir Mikhaylovich Seryh writes that in the history of political and legal thought for the last hundred years there was Marxist doctrine that was the undisputed leader and did not lose its leading position at present, "there is no other theory capable of fully and consistently answering complex questions of law, which other theories cannot reveal." (Seryh, 2001) In another work, the scientist, deals with the characterization of the methodological function of dialectical (and historical) materialism, emphasizes that it... "is expressed in the orientation of the knowing subject to obtain objective-true knowledge, to reveal ways and means of obtaining such knowledge and forms of its objectification, presentation. As universal patterns of scientific knowledge, the principles of dialectical logic form the initial methodological basis for the knowledge of any special, specific science, show the way of understanding objective-true knowledge"(Seryh, 2004).

It seems that the position of American professor Grem Loren Grehem is a convincing confirmation of the significance of the analysed method : "If we recognize the legality of the raising of fundamental questions about the nature of things, the dialectical-materialist approach-scientifically oriented realistic, materialist-claims superiority over existing and competing universal systems of thinking, and these issues can be sufficiently substantiated." (Grehem, 1991) Oleg Aleksandrovich Puchkov, naming and characterizing the main characters of the theory of state and law in the era of domination of communist doctrine there are mythology, autocentrism, speculative, utopianism and orthodoxy, (Puchkov, 2001) nevertheless goes on to write that... "despite the heavy burden of decades of imposed archaic political and legal provisions... the science of the state and law is evolving now. It is exempt from those scientific constructions that do not allow to explain complex phenomena of political and legal reality and is looking for new approaches "(Puchkov, 2001).

Alexander Ivanovich Demidov is more skeptical about the process of the development of the domestic theoretical science. He notes the retardation of the methodology, which in an effort to preserve the usual and indeed much explaining Marxist paradigm of interpreting legal reality, which.." explains the legal reality by such categories as classicity, formationalism, economic determination of state-legal phenomena, their superstructure character and development according to the" laws of dialectics, "identification of revolutionism with fundamentality, depth of transformation." And this methodology... "is adjacent to the visible recognition of the need for changes, but within the usual style of thinking". It is the dialectical method that is defined as the main method that allows to reveal the patterns of development of a legal phenomenon, (Petrov, 2019) it is used by scientists in the preparation of theses for the degree of candidate (doctor) of legal sciences. Sergey Ivanovich Svepkin, in the dissertation abstract of his $\mathrm{PhD}$ thesis, states that in his work he was guided by "a dialectical understanding of the process of historical development, based on recognition of the conditionality of the pattern of events and phenomena in history" (Svyatkin, 2020). 


\subsection{On Metaphysical Methods of Modern General Theory of State and Law}

Many authors note that the so-called metaphysical methods of the research of the statelegal reality do not "fit" well into the system of other methods, methodologies. For example, Vyacheslav Nikolaevich Zhukov notes that the experience of the XIX and especially of the 20th century has shown that not all philosophical schools have proved fruitful in methodological terms for the philosophy of law. The scientist also argues that "often lawyers artificially, very arbitrarily tried to combine philosophy and jurisprudence and thus proved not so much the possibilities of the philosophy in the field of the knowledge of law as their own possibilities in the framing of thinking schemes," referring to such, "natural, invented concepts built on the basis of phenomenology and existentialism" (Zhukov, 2019).

As for our attitude to the possibilities of the using of the potential of another method, hermeneutics in law, it is quite critical as an attitude of a number of scientists (Vlasenko). For example, Vladimir Mikhailovich Seryh, in our opinion, strongly showed the futility of hermeneutics as a method of knowledge in law (Seryh, 2007). It seems, and most likely this circumstance, that this method is rarely included in the system of methods of knowledge of the law. It should be noted that even those scientists who placed certain hopes on the legal hermeneutics in the research, at present they began to doubt its potential. For example, Iliya Chestnov's monograph "Legal Understanding in the Post-Modern Era" deals with phenomenology, hermeneutics, synergetics, etc., and its author concluded that these approaches to law as independent have not taken place yet. "(Chestnov, 2002). So Igor Yurevich Kozlikhin notes that the last decade is characterized by the search for a new paradigm. It is tried to find outside the Law, to involve the knowledge of other sciences by the study of the law. This is most appeared in the general theory. The scientist believes that such attempts should be welcomed, but only if they deepen our knowledge of the law and not of the subject matter of the sciences to which we turn (Kozlikhin, 2006). The main discussion question of this work deals with the hierarchy of the modern legal sciences, which theoretical scientists solve in different ways.

\section{Conclusion}

In this part of the article, it should be noted that the diminution of the status of the general theory of the State and law at the theoretical level, which deplores the education of modern lawyers, leads to the collapse of the domestic legal science, which recognized at all stages of its development (pre-revolutionary, Soviet, post-Soviet) the fundamental, methodological nature of the first $[37 ; 38]$. And attacks on the theory of the state and law gradually turned into a practical plane: the abolition of the state examination in this discipline, the reduction of teaching hours, the refusal of some legal journals (for example, "Modern Law," Journal of St. Petersburg University, etc.) to print scientific articles on the general theoretic issue, etc.

We believe that such abnormal situation should be corrected, focusing on the Nicholas Korkunov's statements, the founder of the theory of the state and law, that "the general theory of law (and the theory of the state - Kozhevnikov Vladimir Valentinovich) is... the cornerstone of the legal system "(Radko, 2009). Justifying the significance of the theory of state and law, modern theoretical scientist Yuri Ivanovich Grevtsov, in our opinion, argues the following: "The point of the training of a lawyer is not that he learned by heart and in detail the norms in force today. It is unlikely that he will need it in ten years in a professional activity for which most of these norms will not be necessary. But it is important for him to understand the structural relationship of norms, the terms he operates, the ways he uses to fix norms and their consistency. "(Grevtsov, 2019).- In justifying of his position, which 
undoubtedly is supported, Yuri Ivanovich Grevtsov gives a statement of recognized authority in the field of the comparativistics René David, who wrote the following: "The legal norms can be changed. But there are many elements in them that cannot be arbitrarily changed, because they are closely related to our civilization and our way of thinking. The legislator cannot influence these elements, just as our language or our manner of thinking "(David, 1996.

We believe that, first, it is necessary to have a discussion with those scientists who downplay the high status of the general theory of state and law in their publications at the theoretical level. Secondly, to criticize the practical activities of the state bodies, the editorial offices of legal journals and higher education institutions, which also infringe on this essential legal science, which objectively leads to the depletion of the education of modern lawyers and leads to the undermining of the legal science.

\section{References}

Baranov Pavel Petrovich, Vereshchagin Victor Yuryevich, Kurbatov Vladimir Ivanovich, Ovchinnikov Alexey Igorovich. (2004). Philosophy of law: study guide. Rostov on Don: Publishing house Phoenix. P.3

Baranov Vladimir Mikhail, Pershin Victor Borisovich., Baranova Marina Vladimirovna. (2007). Place and Role of Materialist Dialectic Method in Legal Study//Philosophy of Law. № 3.P. 10.

Bayniyazov Rustam Suleymanovich. (2001). Philosophy sense//Law. №. 5. P. 19.

Bryzgalov Andrey. (2004). On some theoretical and methodological issues of the legal science at the present stage//State and law.№4. P. 17.

Chetvernin Vladimir Alexandrovich. (2003). The concept of law and state. Introduction to the course of the theory of law and the state. M .: Publishing house of the Institute of State and Law of the Russian Academy of Sciences. P.111

Chestnov Ilya Leonidovich. (2002). Law understanding in the post-modern era: monograph. $\mathrm{SPb}$ : SPB Publishing House of the $\mathrm{SPb}$ institute of Foreign Economic Relations, Economics and Law. P. 272.

David René, Joffre-Spinozy Camila. (1996). Basic Legal Systems of Modern Times/From Franch by Vladimir Alexandrovitch Tumanov. M. P. 19-20.

Demidov Andrey Ivanovich. (2001). About the methodological situation in jurisprudence//Jurisprudence. №4. P. 16.

Ekimov Anisim Ivanovich. (1996). Political Interests and Legal Science//State and Law. №12. P.3-4.

Granin Daniil Aleksandrovich. (2000). High sign of St. Petersburg. SPb: Publishing house"Logos". P.174.

Grehem Loren Grem. (1991). Natural Science, Philosophy and Science of Human Behavior in the Soviet Union. M.: Politizdat . P. 15.

Grevtsov Yury Ivanovich. (2019). Lectures on general theory of law: Tutorial. SPb: Publishing house $\mathrm{SPb} /$ Unta. P. 22.

Korelsky Viktor Mikhailovich. (2000). Methods of the theory of state and law // Theory of state and law: textbook / ed. Victor Mikhailovich Korelsky, Victor Dmitrievich Perevalov. M. Publishing house INFRA-M. P. 12-13.

Kozhevnikov Vladimir Valentinovich. (2014). On the question of the criteria of truth of knowledge about the state and law // Modern Law .№2. P.12-16.

Kozlikhin Igor Yurevich. (2006). On unconventional approaches to the law//Law.№1. P. 31 . 
Kozhevnikov Vladimir Valentinovich. (2018). General theory of state and law: in defense of basic, methodological science//Journal of the Omsk State. Series "Law". №4. P. 72-79.

Kozhevnikov Vladimir Valentinovich. (2019). General theory of law: history and modernity (to the 110th anniversary of Andrei Ivanogvich Denisov)/edd. Mikhail Marchenko. M.: Publishing house Prospect, 2018. - 416 p.//State and Law. № 11.P. 154-156.

Kokhanovsky Valery Pavlovich, Przhlensky Vladimir Igorevich, Sergodeeva Elena Aleksandrovna. (2005). Philosophy of Law: Tutorial. M. - Rostov on Don: Publishing House of IKC "Mart,".P.127-128.

Martysciin Orestes Vladimirovich. (2002). On the Concept of the Textbook of Theory of State and Law//State and Law. P. 66.

Polyakov Andrey Vasilievich, Timoshina Elena Vladimirovna, Romashov Roman Anatolyevich. (2000). Theory of the State and Law at the Turn of the Century//Law. №3. P. 244.

Puchkov Oleg Aleksandrovich. (2001). Theory of State and Law: Problems and Perspectives//Law. №6. P. 5-6.

Petrov Alexey Aleksandrovich. (2019). Decisions of the Constitutional Court of the Russian Federation in the doctrine and practice of constitutional justice. autoabstract ... $\mathrm{PhD}$ in Law. Omsk,. P.9.

Radko Timofey Nikolaevich. (2009). Lectures on the state theory and law. M.: Publishing house Prospect. P. 217.

Radko Timothy Nikolayevich, Lazarev Valeriy Vasilevich, Morozova Ludmila Alexandrovna. (2012). Theory of the State and Law: Textbook. M.: Publishing house Prospect. P. 13.

Romashov Roman Anatolyevich. (2010). Theory of the State and Law. Short course. SPb: Peter Publishing House Piter. P. 4, 5.

Sinyukova Tatyana Vitalyevna. Legal Awareness and Legal Education//Theory of the State and Law: Textbook/eds. Nikolay Ignatievich Matuzov and Alexander Vasilevich Malko. M.: Publishing house Jurast. P. 615.

Short philosophical dictionary/eds. Mark Moiseyevich Rosenthal and Pavel Fedorovich Yudin. M.: Gospolizdat. (1941). P. 47.

Seryh Vladimir Mikhaylovich. (2001). Theory of the state and Law: Textbook. M.: Yusticinform Publishing House. P. 478.

Seryh Vladimir Mikhaylovich. (2004). Logical bases of the general theory of law in 2 volumes. T.1. Element structure. M.: Publishing House of ZAO "Yusticinform. P. 188.

Seryh Vladimir Mikhailovich. (2007). Hermeneutic Circle as Methodological Impasse//Modern Methods of Research in Law/edd. Nikolai Ignatievich Matuzov, Alexander Vasilevich Malko. Saratov: Publishing House of the Ministry of Internal Affairs of the Russian Federation. P. 193-235

Svyatkin Sergey Ivanovich. (2020). Soviet Bar and territorial bar associations in Western Siberia in the 1960s - early 1990s. autoabstract ...PhD in Law. Omsk,. P. 14.

Temnov Evgeny Ivanovich. (1997). Method of the Theory of State and Law //General Theory of Law and State: Textbook/eds. Valery Vasilevich Lazarev. M.: Publishing house

Temnov Evgeny Ivanovich. (1992). On the deideologization of methodological approaches in historical, political and state-legal research//State and Law. №3.P. 75.

Zhukov Vyacheslav Nikolaevich. (2019). Philosophy of law: a textbook. -M .: World of Philosophy Publishing House, Algorithm . P.39.

Vlasenko Nikolay Aleksandrovich. Methodological Problems of Modern Law Theory//Journal of Russian Law. № 4.P. 8. 